\title{
Das prateleiras paraaEconomia
}

Prateleiras cheias... Esta é a imagem que me vem à mente quando penso na pesquisa brasileira na área médica. Prateleiras cheias de teses bem elaboradas, que tomaram tempo, dinheiro e disposição de pesquisadores abnegados, muitos com pouca formação prévia, que tiveram que obter a habilitação necessária para elaborar a pesquisa no período de pós-graduação uma vez que não haviam passado por uma fase de iniciação científica na escola médica. Apesar de todo este investimento pessoal, público e privado o resultado quase sempre fica esquecido nas bibliotecas hospitalares ou é apenas citado reverencialmente em outras publicações que provavelmente serão igualmente esquecidas.

Aqui pretendemos discutir o relacionamento entre ensino e pesquisa e seu destino final para a sociedade. A integração ensino-pesquisa é considerada por todos como útil e necessária e, no entanto, tem sido muito difícil de conseguir. Do ponto de vista histórico, as universidades brasileiras são recentíssimas - datam dos anos 1930. As primeiras escolas superiores foram criadas por D. João VI - a Academia Militar, no Rio; as Escolas de Medicina, no Rio e Bahia, e as Escolas de Direito, em São Paulo e Recife. De lá para cá, as escolas superiores têm tido como objetivo quase único a formação de profissionais liberais para o mercado de trabalho. A comparação com outros países mostra que a função de formação de profissionais - pessoas dotadas de uma qualificação específica, legalmente reconhecida - nem sempre é o centro das atividades das universidades, que possuem também funções de pesquisa, de formação cultural.

No Brasil, no entanto, os termos "universidade" e "escolas superiores" chegam a ser sinônimos e a relação entre ensino profissional e ciência tem sido, historicamente, bastante problemática. Isto acontece em muitos países e, talvez, a Alemanha, já desde o século XIX, seja o único caso de uma união efetiva entre o ensino profissional e a pesquisa científica na universidade. Os Estados Unidos, atualmente, possuem pesquisa científica de alto nível nas universidades, mas ela está ligada, principalmente, à formação de cientistas profissionais e não de profissionais liberais - médicos, engenheiros etc. - como no Brasil. Outros países desenvolvidos tendem a manter seus sistemas de pesquisa científica desligados das universidades sendo os exemplos mais conhecidos a França, com o Centre National de la Recherche Scientifique e a Rússia com a Academia de Ciências, ambos mantendo ligações tênues com os respectivos sistemas nacionais de educação para as profissões.

Independente desta relação, uma das características da ciência moderna é a institucionalização da pesquisa científica como uma atividade profissional, bem remunerada e em regime de tempo integral.

0 trabalho científico baseia-se em talento e em pessoas habilitadas, que só são atraídas para esse tipo de atividade se tiverem liberdade para saciar sua curiosidade e enfrentar os desafios intelectuais que ocorrem nos seus campos do conhecimento, além de serem econômica e psicologicamente recompensadas por suas realizações. Isso, por sua vez, requer a existência de instituições e agências que aceitem, apóiem e recompensem essas atividades. Uma vez que só os cientistas podem avaliar a qualidade, em termos intelectuais, do próprio trabalho, eles necessitam de instituições profissionais e entidades afins para estabelecer contatos e intercâmbios, através dos quais os valores da excelência científica possam ser estimulados. Isto faz com que a maioria dos pesquisadores anseie estar inserida em meios acadêmicos para desempenhar suas funções.

Entretanto, temos que cuidar para que o equilíbrio entre o útil e o necessário esteja contemplado. Uma sociedade que considere que apenas o título acadêmico seja de interesse relevante pode levar a futilidade intelectual, do mesmo modo ao recompensarmos apenas os produtos tecnológicos da pesquisa, e não a pesquisa per se, estaremos desestimulando carreiras científicas em favor de empreendimentos comerciais puros.

De certa forma, o sistema tradicional de universidades nacionais tem privilegiado a carreira acadêmica e pouco tem conseguido transferir os conhecimentos adquiridos para a iniciativa privada. Por outro lado, a própria academia, em raras oportunidades tem procurado a iniciativa privada para encontrar temas atuais e de utilidade pública. Por esta ótica, se perguntarmos pela demanda por pesquisa e treinamento de alto nível num contexto de subdesenvolvimento, veremos que os padrões tradicionalmente baixos das grandes universidades dos países subdesenvolvidos são, em geral, adequados à demanda pouco qualificada dos respectivos mercados de trabalho.

$\mathrm{Na}$ ausência de uma política mais agressiva de independência tecnológica, as pesquisas científicas que esporadicamente se iniciam tendem a se transformar em simples exercícios acadêmicos.

Temos, portanto, um caso típico de um sistema de "negação circular", onde as sociedades estagnadas demandam pouco de suas universidades, o que desestimula a emergência de melhores padrões de trabalho profissional, técnico e científico, o que reduz a motivação para que pessoas de talento sejam atraídas para as áreas científicas e técnicas, 0 que contribui para a estagnação geral da sociedade e assim por diante.

Este círculo vicioso poderia ser quebrado com instituições híbridas que contornassem o sistema universitário e suas estruturas burocráticas, administrativas e políticas e atingissem as cadeias produtivas e seus fluxos de financiamento. Instituições marginais podem fornecer um 
treinamento profissional de alta qualidade em pesquisa, além de encampar os profissionais provenientes das universidades que tivessem um veio científico apesar da formação clínica. Quando essas instituições isoladas vão mais adiante, no entanto, e buscam, além de um ensino técnico e profissional de melhor nível, o desenvolvimento da atividade científica, seu potencial de transformação social pode ser bastante significativo. Nesses casos, elas funcionam como bolsões de formas inusitadas de pensar e trabalhar, de concepções alternativas e inovadoras a respeito da realidade circundante e da própria natureza da atividade universitária. Nesse caso, o objetivo é intensificar a cooperação junto a empresas com as quais a universidade já se relaciona adotando iniciativas como a realização de w orkshops, programas de propriedade intelectual, incremento a programas de incubadoras de empresas e procura de fundos setoriais para financiamento de projetos de pesquisa.

Apesar de haver agências de fomento nas quais 0 pesquisador busca dinheiro individualmente, além de outras onde a busca tem de ser feita pela instituição de ensino, pode haver a procura por financiamento de maneira compartilhada.
Formação, Financiamento, Inteligência, Necessidade e Demanda, talvez estas cinco pilastras possam sustentar uma concepção alternativa onde a curiosidade médica se alie às dificuldades sentidas no desempenho das funções clínicas gerando idéias originais e inovadoras a serem desenvolvidas por profissionais habilitados na resolução de problemas, propiciando soluções férteis e viáveis, para que a iniciativa privada produza e comercialize.

Este conceito poderia ser a gênese de uma solução auto-sustentada para a ciência médica brasileira, criando institutos de pesquisa associando a academia à indústria, formando profissionais híbridos e conscientes de suas atribuições profissionais e sociais. Estabelecendo autonomia e independência intelectual para a Medicina brasileira e para o país.

Henrique Olival Costa 